\title{
Effect of Pruning Severity on Flowering and Fruiting of Mango (Mangifera indica) cv. Alphonso in Off-Year Season
}

\author{
M. A. Elkhishen \\ Department of Pomology, Faculty of Agriculture, Cairo \\ University, Cairo, Egypt.
}

\begin{abstract}
7 HIS study was conducted in two successive seasons 2011-2012 and 2012-2013 in a private orchard to evaluate the effect of after setting pruning (at the first week of June) of non bearing shoots in the On-year for enhancing some flowering and fruiting attributes in the next off-year of Alphonso mango cultivar . Trees were subjected to four pruning treatments, removing half length of the terminal shoots, removing the whole terminal shoots, tipping and the control (without pruning). The highest number of emerged shoots per pruned shoot was achieved by removing half length of the terminal shoots, this treatment recorded the highest reserve of total sugars and $\mathrm{C} / \mathrm{N}$ ratio in the leaves at the time of flower bud differentiation, moreover this treatment was fulfilled the highest number of flowering shoots, number of panicles per tree, panicle length, perfect flowers percentage, fruit retention and yield. Removing half length of the terminal shoots in On-year of Alphonso mango cultivar proved to be the most effective treatment to regulate tree yield of Alphonso cultivar.
\end{abstract}

Keywords: Mango, Pruning, Alternate bearing, Flowering, Fruiting, Fruit retention, Yield.

Mango is considered one of the most important tropical fruits of the world (Nafees, et al., 2010).There are many important commercial mango cultivars in Egypt, one of them is Alphonso, which suffered from irregular bearing under Egyptian conditions. This cultivar could produce high yield in a year, following by lower yield in the following year with a moderate yield in the next one. This phenomenon is vital affecting the regulating of fruit bearing. Pruning could be performed after fruit setting to ensure that bearing shoots mature for next crop (Shaban, 2009 and Khattab, et al., 2009). This cut removes the growth flushes that occurred during the previous season and replaced in the fruit set growth period. Pruning branches can produce new shoots which used to produce fruits in the next off- year. Therefore, pruning of mature trees after fruit setting is used to regulate bearing in the next year (Khattab et al., 2009). Pruning is commonly used as a mean to synchronize the vegetative reproductive cycle of trees and control of mango trees size ( Davenport, 2006). (Crane, 2004). The age of the last flush is the dominant factor regulating flowering of mango. Stems must be generally about 4 to 5 months to be able to induce for flowering in the next year (Davenport, 2003). Pruning after fruit set induced new vegetative growth (Reddy, 
1983). Pruning shoots in mid July affects the production and growth of new shoots and the subsequent flowering (Kumar and Reddy, 2007). (Crane, 2004) used pruning after fruit set to increase the number of emerged shoots but pinching decreased the number of emerged shoots, while pruning treatments in January increased the number of emerged shoots (Shaban, 2005). However, pruning can regulate the bearing in the off-season (wilkie et al., 2008). Moreover pruning treatments increased sex ratio of panicles (Sharma and Room, 2006). Also (Lal and Burondkar et al., 1997) reported that pruning enhanced flowering compared to unpruned trees. Also pruning can increase clearly fruit retention\% (Khattab et al., 2009). Moreover, pruning of mango Honygold cultivar resulted on increasing the yield (Wilkie et al., 2008).

This study aimed to investigate the effect of pruning levels after fruit set in the On-year on flowering and enhancing yield in the next off- year of Alphonso mango trees.

\section{Materials and Methods}

This experiment was carried out in two successive seasons of 2011-2012 and 2012-2013 at private orchard located at El Wadi-Elfaregh, Cairo-Alex desert road on Alphonso mango trees planted in sandy soil at 7 x 6 meters apart. Trees were about 16 years old grafted on seedling rootstocks and received the recommended management practices of the orchard. The selected Alphonso trees were similar in growth vigor in the On- year season. Pruning treatments were applied after fruit set in June by pruning the terminals that failed to bear fruit at the On-year season. Chosen trees were 32 trees in each season in On-year. Each treatment comprised 8 trees, 4 trees for taking samples for chemical analysis and the other 4 trees for measurements in the orchard. There are 4 levels of pruning as following, no pruning (control), tipping, removal of half length of the terminal shoots, removal of the whole terminal shoots. These treatments were applied to the trees in On-year, and then the experiment was completely repeated in the next season on other bearing trees, also on the On-year trees. 25 unfruitful terminal shoots per tree were tagged. The complete randomized design was arranged with one tree for each replicate.

Number of emerged shoots per pruned shoot was measured in December (after 6 months of pruning).

The average number of flowering shoots per emerged shoots was counted in April of the off season.

The panicles length $(\mathrm{cm})$ and the total number of panicles per tree were measured at the end of April in the off-year.

Percentage of the perfect flowers was calculated as follows: no. of perfect flowers /total number of flowers x 100.

Egypt. J. Hort. Vol. 42, No.2 (2015) 
Percentage of fruit retention was calculated as fruit retention\%=ultimate fruit set /initial fruit set x 100 .

The total numbers of fruits per tree were counted before harvest and the yield $(\mathrm{kg})$ was estimated by multiplying number of fruits per tree $\mathrm{x}$ average fruit weight at harvest.

$\mathrm{C} / \mathrm{N}$ ratio was determined in leaves at the time of flower bud differentiation at the second week of December (Khattab et al., 2009) according to the following equation:

$\mathrm{C} / \mathrm{N}$ ratio=total carbohydrate /total nitrogen $\mathrm{x}$ 100. Percentage of carbohydrate was determined according to Duboise et al. (1956), while \% N was determined according to Jackson (1967).

The total sugar content was determined in the same time (at the second week of December) according to Sadasivam and Manickam (1996).

The data were analyzed by analysis of variance (ANOVA) using the general linear models "GLM" procedure of the SAS software (version 9.0, SAS Institute, Cary, NC, 2002). Significant differences between treatments were assessed by means of multiple Duncan range test (Duncan, 1955).

\section{Results and Discussion}

Average number of emerged new shoots per pruned shoot

Data in Table 1 proved that all pruning treatments after fruit set on Alphonso trees increased significantly the average number of emerged shoots per pruned shoot compared to the control trees in the On-year. A significant difference was found between the three pruning severities thus removing half length of the terminal shoots recorded the significant highest average number of emerged shoots per pruned shoot compared to the other pruning treatments .Also there was a significant difference between removing the whole terminal shoots and tipping treatments. The same trend was repeated in the second season with the same significant differences (Table 1). These results are in agreement with Kulkarn (1983) who reported that pruning of Alphonso mango trees resulted in immediate production of vegetative growth. Nunez-Elisea et al. (1996) reported that removing apical buds of mango by pruning promote initiation of shoots from auxiliary buds. Moreover, Davenport, (2006 reported that pruning treatment increased the emerged shoots per pruned shoot. These results are in harmony with those recorded by Shaban (2009) who reported that pruning significantly increased number of new developed flushes per pruned shoot over the control.

Average number of flowering new shoots per pruned shoot

Data in the same Table 1 indicated that a significant increase was detected in the average number of flowering new shoots per pruned shoot in the off year by all pruning treatments. This increase was the highest significant with removing 
half length of the terminal shoots compared to the other pruning treatments. Also removing the whole terminal shoots significantly increased number of flowering shoots in the off- year compared to tipping treatment. These results were resulted with the same significant difference in the second season with the same trend as shown in the same Table 1. It seems that the average number of flowering shoots per pruned shoot in the Of-year based on the number of bearing units which exist as a result of pruning in the On-year which increased these bearing units by enhancing the vegetative growth in On-year. also it seems that removing the half terminal shoots was the highest pruning treatment for increasing vegetative growth so it recorded the highest average number of flowering shoots which increased by the increasing in emerged shoots. This result was in line with those recorded by Ingle et al. (2001), Mohan et al. (2001), Yeshitela et al. (2003), Kumar \& Reddy (2007), Shaban (2009) and Kattab et al. (2009) they reported that pruning after fruit set increased significantly the number of flowering shoots per pruned shoot in the off year comparing to unpruned trees. This increase may help mango trees in the off year to promote flowering and it has regulated the mango bearing in the off year.

TABLE 1. Effect of pruning severity on AV. no. of emerged shoots, Av. no. of flowering shoots per pruned shoot and no. of panicles per tree, seasons 2011-2012 and 2012-2013.

\begin{tabular}{|l|c|c|c|c|c|c|}
\hline \multirow{2}{*}{$\begin{array}{c}\text { Pruning } \\
\text { treatments }\end{array}$} & \multicolumn{2}{|c|}{$\begin{array}{c}\text { Av. no. of emerged } \\
\text { shoots }\end{array}$} & \multicolumn{2}{c|}{$\begin{array}{c}\text { Av. no. of } \\
\text { flowering shoots / } \\
\text { pruned shoot }\end{array}$} & \multicolumn{2}{c|}{$\begin{array}{c}\text { No. of panicles / } \\
\text { tree }\end{array}$} \\
\cline { 2 - 8 } & $\mathbf{2 0 1 1 - 2 0 1 2}$ & $\mathbf{2 0 1 2 - 2 0 1 3}$ & $\mathbf{2 0 1 1 - 2 0 1 2}$ & $\mathbf{2 0 1 2 - 2 0 1 3}$ & $\mathbf{2 0 1 1 - 2 0 1 2}$ & $\mathbf{2 0 1 2 - 2 0 1 3}$ \\
\hline Control & $1.1^{\mathrm{d}}$ & $1.2^{\mathrm{c}}$ & $1.0^{\mathrm{d}}$ & $1.0^{\mathrm{d}}$ & $93.7^{\mathrm{c}}$ & $87.7^{\mathrm{c}}$ \\
\hline $\begin{array}{l}\text { Removing } \\
\text { half of } \\
\text { terminal } \\
\text { shoots }\end{array}$ & $3.5^{\mathrm{a}}$ & $3.7^{\mathrm{a}}$ & $2.6^{\mathrm{a}}$ & $2.6^{\mathrm{a}}$ & $205^{\mathrm{a}}$ & $216.7^{\mathrm{a}}$ \\
\hline $\begin{array}{l}\text { Removing } \\
\text { whole of } \\
\text { terminal } \\
\text { shoots }\end{array}$ & $2.63^{\mathrm{b}}$ & $2.4^{\mathrm{b}}$ & $1.7^{\mathrm{b}}$ & $1.5^{\mathrm{b}}$ & $153.7^{\mathrm{b}}$ & $160.3^{\mathrm{b}}$ \\
\hline Tipping & $2.33^{\mathrm{c}}$ & $2.3^{\mathrm{b}}$ & $1.4^{\mathrm{c}}$ & $1.3^{\mathrm{c}}$ & $164.3^{\mathrm{b}}$ & $167.3^{\mathrm{b}}$ \\
\hline
\end{tabular}

indicate significant differences according to means of multiple Duncan range tests $(\mathrm{P}<0.05)$.

\section{Number of panicles per tree}

Data in Table 1 proved that removing half of the terminal shoots increased significantly number of panicles per tree in the off-year compared to the other pruning treatments. Also tipping and removing the whole terminal shoots increased the number of panicles per tree without significant difference between both treatments. On the other hand, there was a significant increasing in the number of panicles per tree between all pruning treatments and the control trees. The highest number of panicles was recorded by removing half of the terminal

Egypt. J. Hort. Vol. 42, No.2 (2015) 
shoots, the same trend of results was recorded in the next season. Moreover, this number of panicles was increased in the off year based on the increasing in the vegetative growth in the On-year. Thus, the improvements in the tree vegetative growth in the On-year increase the bearing units which increase the number of panicles in the off year. Also the increasing in number of panicles per tree in the off- year may lead to bearing regulation in both seasons, On and off seasons. These results are in harmony with that found by Ingle et al. (2005), Yeshitela et al. (2003), Sharma \& Room (2006) and Kattab et al. (2009) which they reported that pruning clearly increase the number of panicles per tree.

\section{Panicles length $(\mathrm{cm})$}

Data shown in Table 2 cleared that both of control trees (unpruned) and removing half of the terminal shoots had the longest panicles without significant difference between treatments, while both of tipping and removing the whole terminal shoots produced the lowest panicles length without significant difference. These results were detected in both seasons of the investigation. However, it was cleared that both of tipping and removing the whole terminal shoots were not effective in this criteria comparing to control trees. These results were in harmony with those recorded under Indian conditions by Mohan et al. (2001) who reported that pruning treatments reduced panicles length of mango cv. Dashehari. On the other hand, these results were not agree with those reported by Shaban (2009) who reported that moderate pruning recorded the highest panicles length comparing to control trees in mango cv. Zebda.

\section{Perfect flowers percentage}

The perfect flowers percentage was significantly increased by pruning treatments comparing to control trees. Moreover, removing half of the terminal shoots in the On-year significantly increased the perfect flowers percentage in the Off-year, this treatment recorded the highest perfect flowers percentage followed by both of tipping and removing the whole terminal shoots. The same trend was obtained in the second season with the same sequence. From the former data, it was clear that pruning treatments promote these criteria which reflect on some fruiting attributes. The obtained results were in harmony with Shu \& Sheen (1987), Sharma \& Room (2006) and Kumar \& Reddy (2007).

\section{Fruit retention percentage}

The fruit retention percentage was increased significantly with pruning treatments in off-year (Table 2). Removing half of terminal shoots in the On-year significantly increased fruit retention over the other treatments which recorded the highest fruit retention. Moreover, both of tipping and removing the whole terminal shoots significantly increased the fruit retention percentage in the Off year comparing to the control trees but it shows less significant than removing half of terminal shoots. On the other hand, control trees recorded the lowest significant fruit retention percentage. These results were recorded with the same sequence in the second season. The effect of pruning to promote fruit retention percentage may based on the effect of pruning treatments for increasing flowering shoots and perfect flowers percentage in the Off year, while the 
unpruned trees (control) recorded the lowest fruit retention percentage due to the lowest number of flowering shoots and perfect flowers percentage. These results are in line with the finding of Oosthuyse (1992) and Oosthuyse \& Jacobs (1996) as they found that, winter pruning of mango sensation cultivar promotes the percentage of fruit retention.

TABLE 2. Effect of pruning severity on panicle length $(\mathrm{cm})$, perfect flowers percentage and fruit retention percentage seasons 2011-2012 and 2012-2013.

\begin{tabular}{|c|c|c|c|c|c|c|}
\hline \multirow{2}{*}{$\begin{array}{l}\text { Pruning } \\
\text { treatments }\end{array}$} & \multicolumn{2}{|c|}{$\begin{array}{l}\text { Panicle length } \\
\text { (cm) }\end{array}$} & \multicolumn{2}{|c|}{$\begin{array}{l}\text { Perfect flowers } \\
\text { percentage }(\%)\end{array}$} & \multicolumn{2}{|c|}{$\begin{array}{l}\text { Fruit retention } \\
\text { percentage }(\%)\end{array}$} \\
\hline & 2011-2012 & 2012-2013 & 2011-2012 & 2012-2013 & 2011-2012 & 2012-2013 \\
\hline Control & $34.4^{\mathrm{a}}$ & $35.6^{\mathrm{a}}$ & $17.0^{\mathrm{c}}$ & $18.6^{\mathrm{d}}$ & $0.2^{\mathrm{c}}$ & $0.36^{\mathrm{c}}$ \\
\hline $\begin{array}{l}\text { Removing half } \\
\text { of terminal } \\
\text { shoots }\end{array}$ & $34.4^{\mathrm{a}}$ & $35.1^{\mathrm{a}}$ & $21.5^{\mathrm{a}}$ & $23.4^{\mathrm{a}}$ & $1.7^{\mathrm{a}}$ & $1.6^{\mathrm{a}}$ \\
\hline $\begin{array}{l}\text { Removing } \\
\text { whole of } \\
\text { terminal shoots }\end{array}$ & $32.3^{b}$ & $32.8^{b}$ & $20.8^{\mathrm{a}}$ & $21.9^{b}$ & $1.2^{b}$ & $1.16^{\mathrm{b}}$ \\
\hline Tipping & $32.7^{b}$ & $33.1^{\mathrm{b}}$ & $19.9^{b}$ & $21.0^{\mathrm{c}}$ & $1.0^{\mathrm{b}}$ & $1.06^{6}$ \\
\hline
\end{tabular}

\section{C/N ratio}

Results in Table 3 show that removing half of the terminal shoots in On-year significantly increased $\mathrm{C} / \mathrm{N}$ ratio and recorded the highest value comparing to the other treatments followed by removing the whole terminal shoots in On-year followed by tipping treatment. The lowest $\mathrm{C} / \mathrm{N}$ ratio was recorded by unpruned trees (control), moreover all the pruning treatments had a significant difference among them. The same trend was confirmed in the second season. The high ratio of $\mathrm{C} / \mathrm{N}$ recorded may related to the high number of emerged shoots as a result of pruning, also it was cleared that removing half of the terminal shoots in On-year recorded the highest number of emerged shoots with the highest $\mathrm{C} / \mathrm{N}$ ratio content.

Removing half of the terminal shoots after fruit set increase the $\mathrm{C} / \mathrm{N}$ ratio in the leaves during flower bud differentiation. This increase influence the number of flowering shoots which reflect on enhancing the yield compared to the other treatments, the opposite trend was recorded with the control trees.

\section{Total sugars percentage (\%)}

Data in Table 3 cleared that removing half of the terminal shoots in On-year recorded the significant highest percentage of total sugars which stored in the leaves during the time of flower bud differentiation. Moreover, all pruning treatments in On-year significantly enhanced the reservation of sugars in the 
leaves compared to the control trees. These results were confirmed in the second season (Table 3). All pruning treatments increased the total sugar percentage with significant difference between treatments. The high percentage of total sugars reserve in the leaves at the time of flower bud differentiation may led to the increasing in number of flowering shoots, panicles number per tree, fruit retention and fruit yield in the Off-season.

TABLE 3. Effect of pruning severity on $\mathrm{C} / \mathrm{N}$ ratio, total sugars percentage and fruit yield per tree seasons 2011-2012 and 2012-2013.

\begin{tabular}{|c|c|c|c|c|c|c|}
\hline \multirow[t]{2}{*}{$\begin{array}{l}\text { Pruning } \\
\text { treatments }\end{array}$} & \multicolumn{2}{|c|}{$\mathrm{C} / \mathrm{N}$ ratio } & \multicolumn{2}{|c|}{$\begin{array}{c}\text { Total sugars } \\
\text { percentage }(\%)\end{array}$} & \multicolumn{2}{|c|}{$\begin{array}{c}\text { Fruit yield } \\
\text { (kg/tree) }\end{array}$} \\
\hline & 2011-2012 & $2012-2013$ & 2011-2012 & $2012-2013$ & 2011-2012 & $2012-2013$ \\
\hline Control & $8.6^{\mathrm{d}}$ & $9.0^{\mathrm{d}}$ & $14.4^{\mathrm{d}}$ & $14.2^{\mathrm{c}}$ & $13.3^{c}$ & $14.1^{\mathrm{c}}$ \\
\hline $\begin{array}{l}\text { Removing half of } \\
\text { terminal shoots }\end{array}$ & $13.8^{\mathrm{a}}$ & $15.2^{\mathrm{a}}$ & $18.1^{\mathrm{a}}$ & $17.9^{\mathrm{a}}$ & $39.1^{\mathrm{a}}$ & $33.2^{\mathrm{a}}$ \\
\hline $\begin{array}{l}\text { Removing whole } \\
\text { of terminal shoots }\end{array}$ & $11.7^{b}$ & $12.6^{b}$ & $15.7^{b}$ & $15.6^{b}$ & $25.3^{b}$ & $22.1^{b}$ \\
\hline Tipping & $10.93^{c}$ & $11.9^{c}$ & $15.4^{\mathrm{c}}$ & $15.4^{b}$ & $22.1^{\mathrm{b}}$ & $19.8^{\mathrm{b}}$ \\
\hline
\end{tabular}

Yield (Kg/tree)

As shown from Table 3 the yield of Alphonso mango cultivar in the Offseason was significantly increased by pruning treatments compared to unpruned trees. Moreover, removing half of terminal shoots in On-year recorded the significant highest yield in the Off-year followed by both of tipping and removing the whole terminal shoots, while control trees recorded the lowest yield in the Off-year. These results were confirmed by the results in the second season. The high number of emerged shoots which detected by pruning caused the high $\mathrm{C} / \mathrm{N}$ ratio and total sugars percentage reserve in leaves at the time of flower bud differentiation. Also due to these high concentrations of sugars and carbohydrate the number of flowering shoots, number of panicles, percentage of perfect flowers and fruit retention increased, all of these factors could enhance the tree yield in the Off year. According to the former results, removing half of terminal shoots was recorded the highest yield based on the highest number of flowering shoots, number of panicles per tree and fruit retention, also the highest reserve of total sugars and $\mathrm{C} / \mathrm{N}$ ratio in the leaves led to the achievement of this result. $\mathrm{C} / \mathrm{N}$ ratio in relation to flowering in mango has been conducted by a number of workers and it has been indicated that total carbohydrates, sugars and $\mathrm{C} / \mathrm{N}$ ratio may induce flower bud formation in the mango Alphonso CV. However, these studies suggested that although nitrogen and carbon reserves play an important role in flower bud initiation (Raa, 1998). Unpruned trees cannot reserve enough sugars and carbohydrate in the leaves which decrease the number of flowering shoots, number of panicles and fruit retention and finally reflect on fruit yield in the Off-year. 


\section{Conclusion}

It could be concluded that removing half of the terminal shoots after fruit set in On-year of Alphonso mango trees planted under Egyptian desert conditions increased number of emerged new shoots, increase the total sugars and $\mathrm{C} / \mathrm{N}$ ratio which have been reserved in the leaves at the time of flower bud differentiation this is in turn cause an increase in the number of flowering shoots, number of panicles per tree and fruit retention which enhance fruit yield of Alphonso mango trees in the Off-season. Therefore, we can depend on the pruning treatments for regulating fruit bearing in the Alphonso mango cultivar under Egyptian desert conditions.

\section{References}

Burondkar, M.M., Gunjate. R.T., Magjum, M.B., Govekar, M.A and Waghmare, G.M. (1997) Increased productivity of mango orchards by pruning and application of paclobutrazol. Acta Horticulture, 445, 367-374.

Crane, J.H. (2004) Selected cultural techniques to improve production of some subtropical and tropical fruit crops. Acta Hort., 632, 179-187.

Davenport, T.L. (2006) Pruning strategies to maximize tropical mango production from the time of planting to restoration of old orchards. Hort. Sci., 41 (3), 544-548.

Duboise, M.F., Smith, K.A., Gillers, J.K., Hamilton, P.A and Smith, F. (1956) Colorimetric method for determination of sugars and related substances. Anal. Chem. 28, 350-356.

Duncan, B.D. (1955) Multiple ranges and multiple f test: Biometrics, 11,1-42.

Ingle, H.V., Athawale, R.B., Tayde, G.S., Pakhare, G.B. (2001) Effect of severity and time of pruning on flower type, fruit set and fruit retention in old acid lime trees (Citrus aurantifolia). Agric. Sci. Digest., 21 (1), 65-66.

Jackson, M.L. (1967) "Soil Chemical Analysis", $1^{\text {st }}$ ed. Prentice Hall of India Pvt. Ltd, New Delhi, pp. 144-19.

Khattab, M.M., Haseeb, G.M. and Elkhishen, M.A. (2009) The effect of post harvest pruning,GA3 and Ethrel concentrations on some flowering attributes and yield of some mango cultivars. The Bulletin of faculty of Agric. Cairo Univ., 60, 306-314.

Kulkarn, P.B. (1983) Studies on regulation of vegetative growth, flowering and fruit drop in mango (Mangifera indica L.) CV Alphonso. Haryana Agric., 9 (4), 344-345.

Kumar, M.A and Reddy, Y.N. (2007) Effect of pruning on emergence of new laterals, their growth and flowering in different mango cultivars. Journal of Research ANGRAU., 35 (3), 13-17.

Egypt. J. Hort. Vol. 42, No.2 (2015) 
Lal, B. and Duchyan, M.T. (2007) Effect of pruning on growth and bearing behavior of mango cv.chausa. Indian Journal of Horticulture, 57 (3), 268-270.

Nafees, M.A., Raheel, M.T., Moazzam, J., Muhammad, N., Saeed, A., Fakhar U., Zaman, A. and Noor-Un-Nisa, M. (2010) Flushing pattern of mango (mangifera indica L.) cultivars in response to pruning of panicles and its effect on carry over effect of floral malformation. Pak. J. Agri. Sci., 47 (1), 13-18.

Mohan, S., Sant, R., Singh, C.P. and Shukla, P. (2001) Effect of pruning on growth, flowering and fruiting in mango. Indian Journal of Horticulture, 58 (4), 303-308.

Nunez-Elisea, R., Davenport, T.L and Calderia, M.L. (1996) Control of bud morphogenesis in mango by girdling, defoliation and temperature modification. $J$. Hort. Sci., 71, 25-40.

Oosthuyse, S.A. (1992) Ideas on pruning of mango trees. South Africa Mango Growers Assn. yearbook. 12, 1-7.

Oosthuyse, S.A. and Jacobs, G. (1996) Flowering synchronization of sensation mango trees by winter pruning. Acta Hort., 455 (1), 423-430.

Raa, M.M. (1998) Problem of alternate bearing: causes and management in mango cultivation. International book distributing CO. luck now, India, pp. 339-362.

Reddy, K.S. (1983) Interrelationship between vegetative growth and flowering in mango (mangifera indica L.) CV. Banganapalli thesis abstract Haryana agricultural university. 9 (3), 277-278.

Sadasivam, S. and Manickam, A. (1996) "Biochemical Methods", $2^{\text {nd }}$ ed. New Age International (P) Ltd., Publishers, New Delhi, ISBN 8-0976-224-81.

SAS Institute (2002) SAS/STAT User's Guide. SAS Inst. Inc., Cary, NC, USA.

Shaban, A.E.A. (2005) Effect of pruning on growth, flowering and fruiting of Hindi Bisinnara mango trees. J. Agric. Sci. Mansuora Univ., 30 (3), 1541-1550.

Shaban, A.E.A. (2009) Effect of summer pruning and GA3 spraying on inducing flowering and fruiting of Zebda mango trees. World J. Agric. Sci., 5 (3), 337-344.

Sharma, R.R. and Room, S. (2006) Pruning intensity modifies canopy microclimate and influences sex ratio, malformation incidence and development of fruited panicles in Amrapli mango (mangiferaindica L.). Scientia Hort., 109, 118-122.

Shu, Z.H. and Sheen, T.F. (1987) Floral induction in auxiliary buds of mango (Mangifera Indica L.) as affected by temperature. Scientia Hort., 31, 81-87.

Wilkie, J.D., Robertson, D., Olesen, T and Sedgley, M. (2008) The timing of pruning affects flush development and flowering in Honey gold mango. Acta Hort., 787, 241-244.

Egypt. J. Hort. Vol. 42, No.2 (2015) 
Yeshitela, T., Robbertse P.J and Stassan, P.J.C. (2003) The impact of panicle and shoot pruning on inflorescence and yield related developments in some mango cultivars. $J$. Appl. Hort., 5 (2), 69-75.

(Received 7/ 6/ 2015;

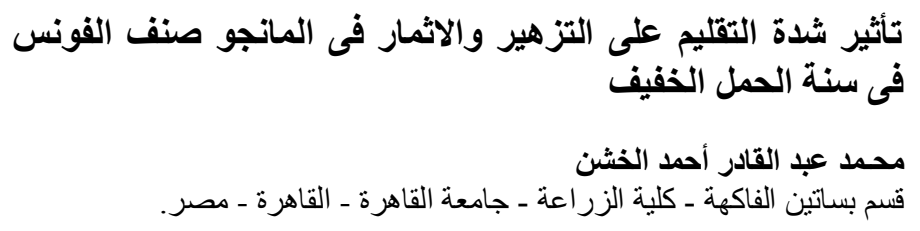

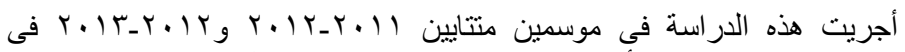

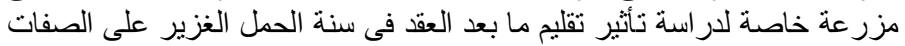

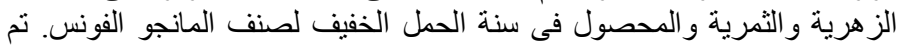

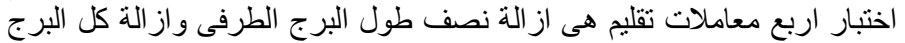

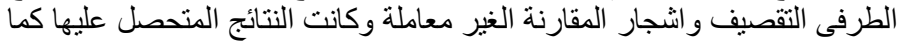

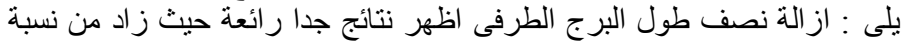

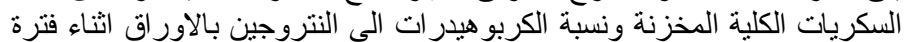

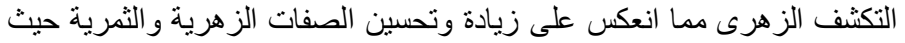

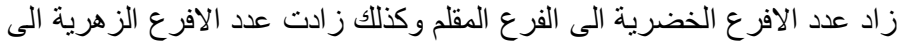

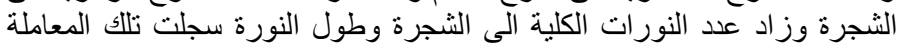

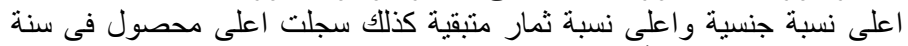

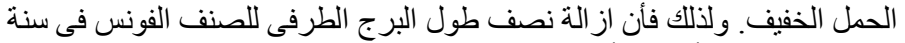

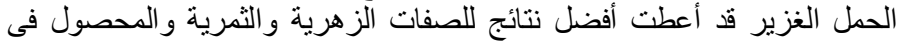

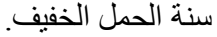

الكلمات الداله: المانجو، تقليم، تبادل الحمل، التزهير، الاثمار، الثمار المتبقية

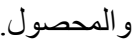

